\title{
Agroforestry for Sustainable Agriculture and Climate Change: A Review
}

\author{
Solomon Abirdew Yirga* \\ Department of Natural Resource Management, Wolkite University, Ethiopia
}

Submission: April 15, 2019; Published: June 03, 2019

*Corresponding author: Solomon Abirdew Yirga, Department of Natural Resource Management, Wolkite University, Wolkite, Ethiopia

\begin{abstract}
The IPCC established that there is accord that the increase of heat tricking gases in the atmosphere will result for climate change ultimately will cause the sea level rise, increased incidence of extreme climatic events including intense storms, flood events and droughts. Therefore, presence of frequent climate-related hazards is causing loss of life and property, social disruption and economic hardships in the Ethiopia. Some scholars investigated that change in climate will have effect on the agricultural productivity, thus food insecurity. Susceptibility is aggravated in Ethiopia due to low adaptive capacity, practices rain-oriented mono-cropping system, widespread poverty and low technology uptake. This paper reviews on agroforestry for sustainable agriculture and climate change adaptation and mitigation in Ethiopia. Agroforestry system is practiced overall the world and it has a major importance for reduction the impacts of climate change. This review dedicated to cross referencing of different studies comprise studies on identified climate changes predominantly concentrating on major climatic components like temperature and rainfall. In addition to this, the role of agroforestry for sustainable agriculture and climate change alleviation are highlighted and several studies are cross referenced and examined. This review also tried to discuss the opportunists and challenges in identifying different land use system that contribute most for food security and climate change alleviation. This can fill the issue of existing research and knowledge gaps. Lastly, the paper deducted to identify research gap and provide the possible solution for identified problem.
\end{abstract}

Keywords: Agroforestry; Sustainable agriculture; Climate change

\section{Introduction}

\section{Background}

Climate change is a change may be due to natural internal processes or external forcing such as modulations of the solar cycles, volcanic eruptions, and persistent anthropogenic changes in the composition of the atmosphere or in land use types. And agroforestry practice is the purposeful growing of trees and crops in interacting combinations began to attain prominence in the late 1970s, when the international scientific community embraced its potentials in the tropics and recognized it as a practice in search of science [1].

During the 1990s, the relevance of agroforestry for solving problems related to deterioration of family farms, increased soil erosion, surface and ground water pollution, and decreased biodiversity was recognized in the industrialized nations too. Thus, agroforestry is now receiving increasing attention as a sustainable land-management option the world over because of its ecological, economic, and social attributes. Consequently, the knowledge-base of agroforestry is being expanded at a rapid rate as illustrated by the increasing number and quality of scientific publications of various forms on different aspects of agroforestry. So, the severity of climate change impact will be reduced by climate change adaptation and mitigation. In many reports, agroforestry practices are absent in the lists and tables of potential mitigation activities. For example, the report on potential management practices to reduce carbon dioxide [2].

However, from the different alternatives of climate change mitigation, agroforestry is the best and can sustain all over the world if we manage in a proper manner. Agroforestry is a climatesmart production system and considered more resilient than mono-cropping in mitigating climate change [3]. Agroforestry, an ecologically and environmentally sustainable land use, offers great promise towards mitigating the rising atmospheric $\mathrm{CO}_{2}$ levels through carbon sequestration [4].

Agroforestry system is practiced overall the world and it has a major importance for reduction the impacts of climate change. However, lack of knowledge, economy, information and technology many developing countries like sub-Sahara African countries do not gave attention to it properly and effectively and overlooked to practice. Nowadays climate change is problem of developed and developing countries. Thus, meet to find out a 
solution to reduce the impacts of climate change on agriculture, biodiversity and food security.

Among the solution recommended by scientists, practicing agroforestry system has a major role for the reduction of climate change impacts particularly total crop failure and reduction on carbon concentration in the atmosphere. Therefore, reviewing the role of agroforestry system on climate change impacts is very important to alarm peoples; NGOs, government and others concerned body to scale up this land use system in their locality, it's important to reduce the effects of climate related hazards associated with total crop failure. The aim of this review is to ascertain the role of agroforestry for climate change adaptation and mitigation.

\section{Results and Discussion}

\section{The History of agroforestry}

Cultivating trees and agricultural crops in intimate combination with one another is an ancient practice that farmers have used throughout the world. Tracing the history of agroforestry [5] states that in Europe, until the Middle Ages, it was the general custom to clear-fell degraded forest, burn the slash, cultivate food crops for varying periods on the cleared area, and plant or sow trees before, along with, or after sowing agricultural crops. This "farming system" is no longer popular in Europe but was widely practiced in Finland up to the end of the last century and was being practiced in a few areas in Germany as late as the 1920s. In tropical America many societies have simulated forest conditions to obtain the beneficial effects of the forest ecosystem. For example, in Central America, it has been a traditional practice for a long time for farmers to plant an average of two dozen species of plants on plots no larger than one-tenth of a hectare. A farmer would plant coconut or papaya with a lower layer of bananas or citrus, a shrub layer of coffee or cacao, annuals of different stature such as maize, and finally a spreading ground cover such as squash.
In Asia, the Hanunoo of the Philippines practiced a complex and somewhat sophisticated type of "shifting" cultivation. In clearing the forest for agricultural use, they deliberately spared certain trees which, by the end of the rice-growing season, provided a partial canopy of new foliage to prevent excessive exposure of the soil to the sun. Trees were an indispensable part of the Hanunoo farming system and were either planted or preserved from the original forest to provide food, medicines, construction wood, and cosmetics [6]. Similar farming systems have also been common in many other parts of the humid lowland tropics of Asia.

The situation was little different in Africa. In southern Nigeria, yams, maize, pumpkins, and beans were typically grown together under a cover of scattered trees (Forde, 1937). The Yoruba of western Nigeria, who have long practiced an intensive system of mixing herbaceous, shrub, and tree crops, claim that the system is a means of conserving human energy by making full use of the limited space won from the dense forest. The Yoruba also claim that this system is an inexpensive means of maintaining the soil's fertility, as well as combating erosion and nutrient leaching [7].

\section{Classification of agroforestry system}

In order to understand and evaluate the existing agroforestry systems and to develop action plans for their improvement, it is necessary to classify them according to some common criteria [8], Therefore, any classification scheme should include ;a logical way of grouping the major factors on which production of the system will depend; indicate how the system is managed (pointing out possibilities for management interventions to improve the system's efficiency); offer flexibility in regrouping the information; and be easily understood and readily handled (practical). Agroforestry systems can be categorized according to these sets of criteria: Structural basis, Functional basis, socioeconomic basis, and Ecological basis [8] (Table 1).

Table 1: Major approach to classification of agroforestry systems and practice [8].

\begin{tabular}{|c|c|c|}
\hline \multicolumn{3}{|c|}{ Categorization of Systems based on their Structure and Functions } \\
\hline $\begin{array}{l}\text { Structure (nature and arrangement of } \\
\text { components, especially woody ones) }\end{array}$ & & $\begin{array}{l}\text { Function (role and/or output of components, } \\
\text { especially woody ones) }\end{array}$ \\
\hline Nature of components & Arrangement of components & $\begin{array}{l}\text { Productive function ((Food, Fodder, Fuelwood, } \\
\text { Other woods and Other products)) }\end{array}$ \\
\hline $\begin{array}{c}\text { Agrisilviculture (Crops and trees } \\
\text { includes shrubs/trees and trees) } \\
\text { Silvopastoral(pasture/animals and trees) } \\
\text { Agrosilvopastoral (crops, pasture/animal: and } \\
\text { trees) }\end{array}$ & $\begin{array}{l}\text { In space (spatial) ((Mixed dense (e.g., } \\
\text { homegarden), Mixed sparce (e.g. most systems } \\
\text { of trees in pastures) and Boundary (trees on } \\
\text { edges of plots/fields Strip (width of strip to be } \\
\text { more than one tree)) }\end{array}$ & $\begin{array}{l}\text { Protective function (Windbreak, Shelterbelt, } \\
\text { Soil conservation, Moisture conservation, Soil } \\
\text { improvement, Shade, (for crop, animal and } \\
\text { man)) }\end{array}$ \\
\hline \multirow{6}{*}{$\begin{array}{l}\text { Others (Multipurpose tree lots, apiculture } \\
\text { with trees, aquaculture with trees, etc.) }\end{array}$} & In time (temporal) & \\
\hline & * Coincident & \\
\hline & * Concomitant & \\
\hline & * Overlapping & \\
\hline & *Sequential (separate) & \\
\hline & * Interpolated & \\
\hline
\end{tabular}




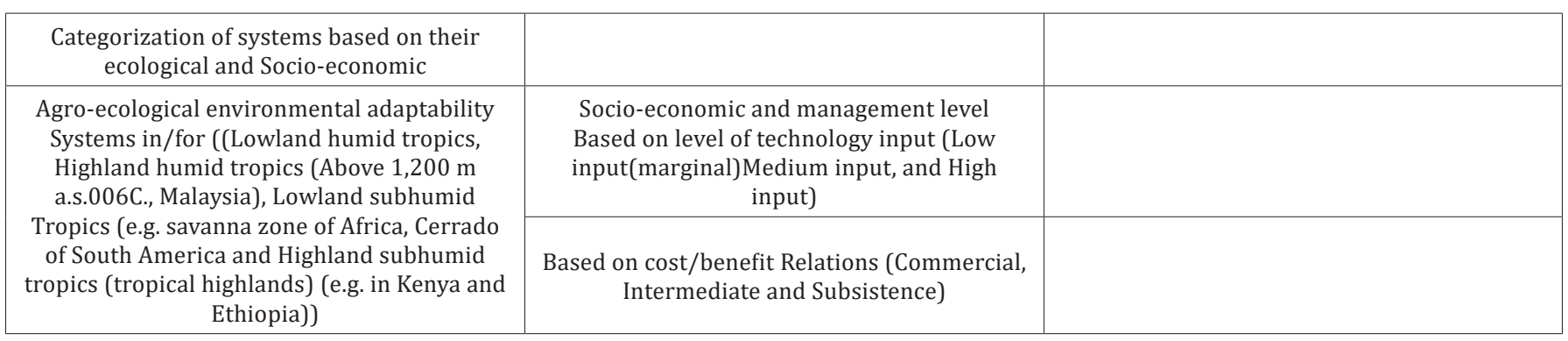

\section{Agro forestry systems in the tropics}

The geographical definition of the word tropics is located between 23.5 degrees north and south of the Equator. It includes the subtropical developing countries that have agro-ecological and socioeconomic characteristics, and land-use problems, that are like those of the countries within the geographical limits of the tropics.

\section{The tropical environment}

The major climatic parameters that determine the environment of a location in the tropics are rainfall (quantity and distribution) and temperature regimes. Altitude is important because of its influence not only on temperature, but also on land relief characteristics. From the agroforestry point of view, the major ecological regions which are relevant and stated are ((temperate, mediterranean, arid and semiarid, subhumid tropical (lowland), humid tropical (lowland) and highland)). Most nations and people in the tropics are poor; gross domestic product per person is low (about $\$ 100-150$ per year) in most of these countries. Economic growth seldom keeps pace with population increase. A vast majority of the people works and depends on the land for their livelihood; yet agricultural production per unit area is very low. The gravity of the situation is compounded by the unfortunate political instability and turmoil that are characteristic of many of these nations, which is a serious impediment to economic development.

\section{Distribution of tropical agroforestry systems}

Lowland humid and sub-humid tropics: Characterized by hot, humid climate for all or most of the year, and evergreen or semi-evergreen vegetation, the lowland humid and sub humid tropics (here after referred to as humid tropics) is by far the most important ecological region in terms of the total human population it supports, extent, and diversity of agro forestry and other land-use systems. In areas with low population density, such as the low selvas of Latin America, trees on rangelands and pastures, improved fallow in shifting cultivation areas, and multipurpose tree woodlots, are the major agroforestry systems. Thus, the common agroforestry systems in this zone are (shifting cultivation, taungya, homegardens, natural rain forest, plantation-crop combination, and various intercropping systems).

Semiarid and arid tropics: Extending over the savanna and Sudano-Sahelian zone of Africa, the cerrado of South America, and large areas of the Indian subcontinent, it is characterized by one or two wet seasons and at least one long dry season. Drought is a hazard in the drier parts of the zone. The predominant agroforestry systems in this zone are - for example, the system based on Faidherbia (Acacia) albida, found in the dry areas of Africa [9-11], and the system based on Prosopis cineraria, found in the dry areas of India [12,13]. Fuel wood shortage, desertification and fodder shortage is a major problem in most parts of the semiarid and arid tropics; agroforestry potentials in fuel wood production are well documented [14].

Tropical highlands: Approximately 20\% of the tropical lands are at elevations from $900-1800 \mathrm{~m}$. The highland tropics with significant agroforestry potential are humid or sub-humid, while areas with dry climates are of very low potential. The overall annual temperatures are low in the highlands (for every $100 \mathrm{~m}$ increase in elevation in the tropics, there is a decline of $0.6^{\circ} \mathrm{C}$ in the mean annual temperature); this affects the growth of certain lowland tropical species. In summary, the major types of agroforestry systems in the tropics are: Humid Lowlands (Shifting cultivation, Taungya, Plantation-crop combinations, Multilayer tree gardens and intercropping systems).Semiarid Lowlands (Silvopastoral systems, windbreaks and shelterbelts, multipurpose trees for fuel and fodder and multipurpose trees on farmlands). Highlands (Soil conservation hedges, Silvopastoral combinations and Plantation-crop combinations).

\section{Agro-ecological spread of tropical agroforestry systems}

There are several socioeconomic factors, such as human population pressure, availability of labor and proximity to markets, are also important determinants of agroforestry system. So that considerable variations can be found among systems existing in similar or identical agro-climatic conditions. Sometimes, socioeconomic factors take precedence over ecological considerations. Even in the case of systems that are found in most ecological and geographical regions, such as shifting cultivation and taungya, there are numerous variants that are specific to certain socioeconomic contexts. The multispecies, multistoried home garden systems serve to illustrate some of these points. Although these systems are found mainly in humid lowlands, they are also common in pockets of high population density in other ecological regions [15].

\section{Attributes of agroforestry}

There are three attributes which, theoretically, all agroforestry systems possess. Productivity: most, if not all, 
agroforestry systems aim to maintain or increase production (of preferred commodities) as well as productivity (of the land). Agroforestry can improve productivity in many ways. These include increased output of tree products, improved yields of associated crops, reduction of cropping system inputs, and increased labor efficiency. Sustainability: by conserving the production potential of the resource base, mainly through the beneficial effects of woody perennials on soils, agroforestry can achieve and indefinitely maintain conservation and fertility goals. Adoptability: the word "adopt" here means "accept," and it may be distinguished from another commonly-used word adapt, which implies "modify" or "change." The fact that agroforestry is a relatively new word for an old set of practices means that, in some cases, agroforestry has already been accepted by the farming community.

\section{The role of agroforestry}

Some of the benefits of agroforestry are; Agroforestry systems play a critical role in moderating the microclimate; Agroforestry systems are highly effective in soil and water conservation through provision of permanent cove; Agroforestry systems offer a major pathway for sustainable diversification of agricultural systems and incomes; Agroforestry systems have the capacity to enhance the use efficiency of rain water; Agroforestry systems provide economically viable and environmentally friendly means to improve soil fertility; Agroforestry systems have the potential to limit carbon emissions and sequester carbon. Source: [16].

\section{Carbon sequestration and agroforestry}

The United Nations Framework Convention on Climate Change (UNFCCC) defines carbon sequestration as the process of removing $\mathrm{C}$ from the atmosphere and depositing it in a reservoir). From the agroforestry point of view, $\mathrm{C}$ sequestration primarily involves the uptake of atmospheric $\mathrm{CO}_{2}$ during photosynthesis and the transfer of fixed $\mathrm{C}$ into vegetation, detritus, and soil pools for "secure" (i.e. long-term) storage (Nair et al. 2010). C sequestration potential (csp) in AGFs: $0.29-15.21 \mathrm{Mgha}^{-1} \mathrm{yr}^{-1}$ aboveground, $30-300 \mathrm{Mg} \mathrm{ha}^{-1}$ up to $1-\mathrm{m}$ depth in the soil. AGFs reduce soil erosion and frequency of disturbance, increase C stability and biodiversity. Effectiveness of $\mathrm{C}$ sequestration depends on (types of AGFs system implemented, climate regimes, Soil type, stage of AGFs development and plant species composition) (Figure 1).

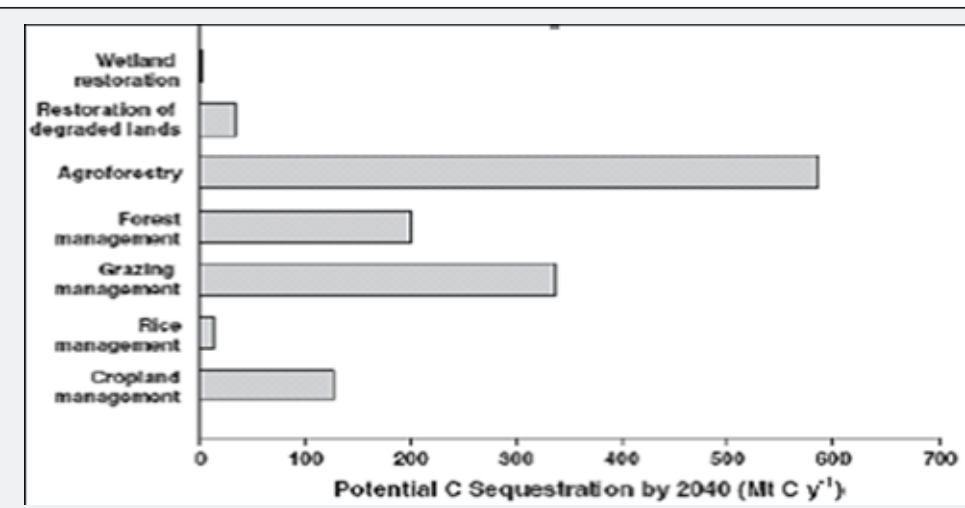

Figure 1: Carbon sequestration potential of different land use and management option in 2040 [17].

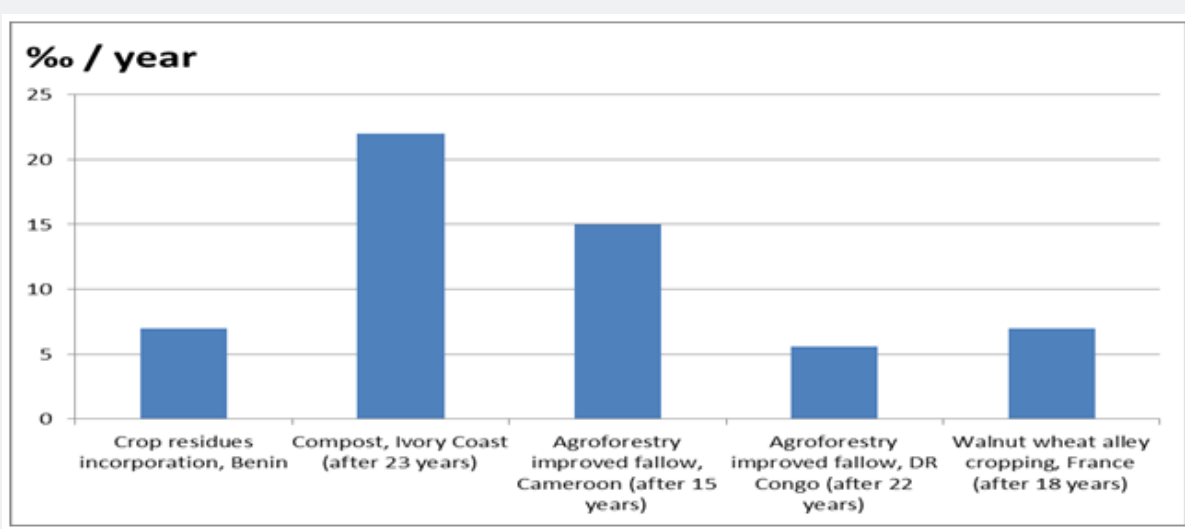

Figure 2: Soil carbon sequestration rates in different practices in different countries [18].

A carbon sequestration rate of $4 \%$ year-1 or more is achievable through different practices: crop residues incorporation, compost, agroforestry, no fire, no overgrazing of past (Figure 2).

\section{Climate change history in ethiopia}

Ethiopia has a long history of coping with extreme weather events. Rainfall is highly erratic and typically falls in the form of intensive convective storms spawned by the country's varied 
topography. Future climate variability and change are expected to worsen these conditions, potentially accelerating already high levels of land degradation, soil erosion, deforestation, loss of biodiversity, desertification, recurrent floods, as well as water and air pollution [19]. According to (NAPA), the agricultural, water resources, and human health sectors will be most negatively impacted by climate change. Based on recent data, the last two hazards appear to be the most significant and are discussed in more detail below.

\section{Droughts and flood events in Ethiopia}

Drought is the greatest and most recurring climate hazard in Ethiopia, and it impacts include pasture shortages, overgrazing, land degradation, decreased water availability, and livestock diseases. All these impacts lead to decreased livestock productivity, crop failure in agro-pastoral areas, food insecurity, and increased conflicts over scarce resources. Droughts also threaten the country's future, as children aged five or less are 36 and $50 \%$ (respectively) more likely to be malnourished if they were born during a drought season (UNDP, 2007/08).

Flash floods occur regularly throughout the country, particularly after a long dry spell. More recently, in the years 1988, 1993, 1994, 1995, 1996, and 2006, major floods inflicted significant losses in terms of human life as well as productive capital. Floods are occurring with greater frequency and intensity across the country due to vulnerabilities imposed by high rates of deforestation, land degradation, increasing climate variability, and settlement patterns.

The 1970s decades' rainfall was more pronounced than the remaining consecutive decades. Its trend shows that declining rainfall up to 1980 s and then starts increasing slightly. The lowest rainfall was observed in 1980s, while the highest rainfall was recorded in 1970s. There is a decline in rainfall amount in the past three decades that is from $1220.3 \mathrm{~mm}$ in 1977 to $821.9 \mathrm{~mm}$ in 2007 with a decline rate of $-1.27 \%$ annually. The lowest rainfall is observed in $1984(511.9 \mathrm{~mm})$, while the highest rainfall is recorded in 1977 (1220.3mm). If we take the average annual rainfall of 31 years, which is $778.6 \mathrm{~mm}$ as a normal annual rainfall, about 12 years (38.7\%) were under normal condition of rainfall. The chronic rainfall shortage was observed in 1984, 1989 and 1994. The major drought years were 1984 and 1994; however, there were several years with lowest precipitation for crop cultivation. Rainfall of Ethiopia decreased almost by $-1.3 \%$ annually.

According to the National Meteorological Agency [20], average countrywide annual rainfall trends remained constant between 1951 and 2006. However, both seasonal and annual rainfall has exhibited high variability. However, some studies have indicated that rainfalls have been declining over some parts of the country. Considerable declining in March-September rainfall was observed in northeast, southeast, and southwestern portions of Ethiopia after 1997 [21]. Rainfall amounts have significantly decreased during the belg (February-May) season. Belg rainfall in the east and southeast exhibited the largest percent reductions. Declines in belg rains may impact long cycle crop production (sorghum) with crippling consequences for agricultural production. In much of Ethiopia, like the Sahelian countries to its west, rainfall from June to September contributes most of the annual total and is crucial to Ethiopia's water resource and agriculture operations [22].

In order to quantify the impact of oceanic events, it found that the sea-surface temperature(SST) over the tropical eastern Pacific Ocean is not significantly correlated with the main rainfall of the semi-arid lowland areas of eastern, southern, and southwestern Ethiopia, except at marginal zones in transition to the Ethiopian Highlands [22]. Indeed, June-September rainfall over the Ethiopian Highlands is positively correlated to the equatorial east pacific sea level pressure and the southern oscillation index, and negatively correlated to SST over the tropical eastern pacific ocean as expected, confirming again that warm phase of ENSO episodes are associated with belowaverage June-September rainfall over the Ethiopian Highlands ( [23] (Figure 3).

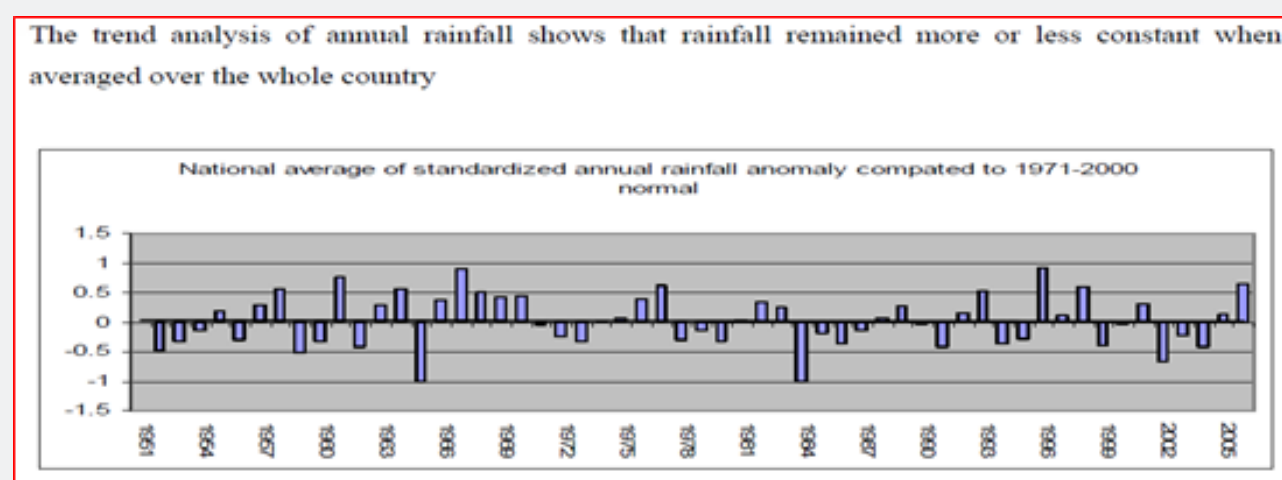

Year to Year Vartability of Annual Rainfall and trend over Ethiopia expressed in Normalized Deviation.

Figure 3: National average of standardize annual rainfall anomaly [21]. 


\section{Source of greenhouse gases emission in Ethiopia}

According to First [24], report the GHG emissions accounted to $900 \mathrm{~kg} \mathrm{CO}_{2}$ equivalent per capita and year in 1994 . The dominant position of livestock farming in Ethiopia's economy also influences the relative contribution of GHG to the total emissions. These are dominated by methane emissions, which account for $80 \%$ of the warming potential. The land-use change \& forestry (LUCF), sector has been a net sink in 1994 which amounted to about $-15,063 \mathrm{Gg}$ of $\mathrm{CO}_{2}$ and the country's stock of natural forests, woodlands, shrubs, and plantations sequestered about -27,573Gg of $\mathrm{CO}_{2}$ in 1994 while emission of $\mathrm{CO}_{2}$ because of deforestation was estimated to be $12,510 \mathrm{Gg}$ in the same year [24] (Figure 4 \& 5, Table 2).

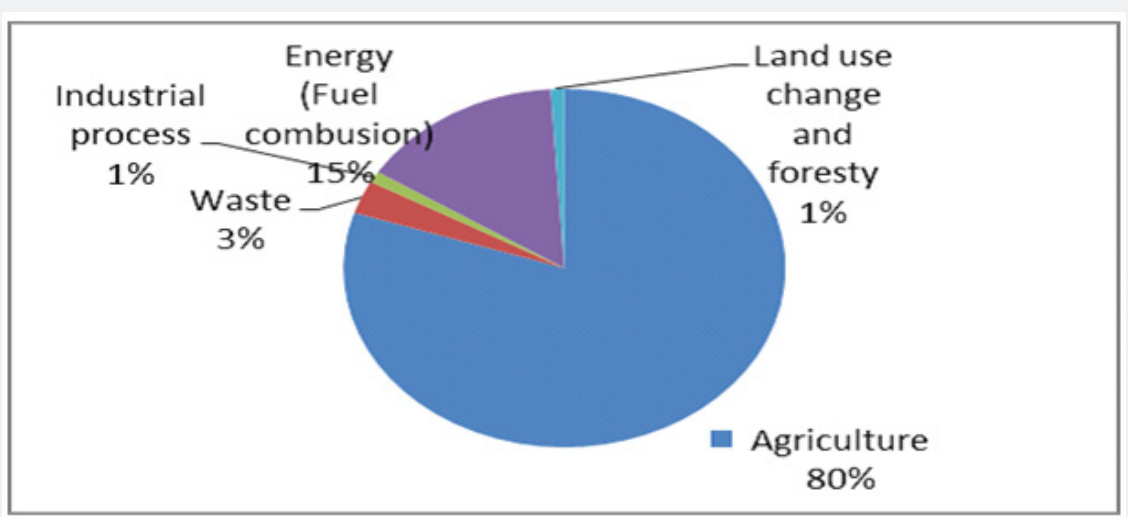

Figure 4: Total greenhouse gases emission by sectors [24].

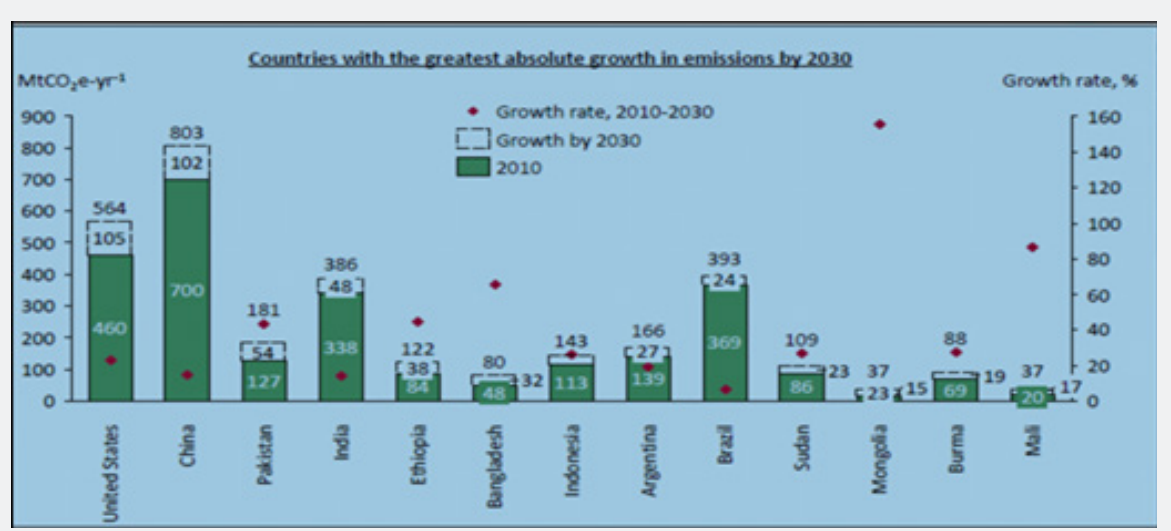

Figure 5: Countries greater emission from agriculture by 2030 [25].

Table 2: Major and minor Emission drivers by sectors and Percent of GHG [26,27].

\begin{tabular}{|c|c|c|}
\hline Sector & Drivers & GHG (\%) \\
\hline Agriculture, Livestock, Soil & $\begin{array}{l}\text { Deforestation, Methane from enteric fermentation, } \mathrm{N} 2 \mathrm{O} \text { from manure left on pastures, Crop } \\
\text { production, Fertilizer use and Manure management }\end{array}$ & 51 \\
\hline Forestry & Forest degradation & 37 \\
\hline Transport & $\begin{array}{l}\text { Passengers (inner-city,intra-city, and international) Freight (dry, construction and mining, and } \\
\text { international cargo }\end{array}$ & 3 \\
\hline Buildings and cities & $\begin{array}{c}\text { Chemicals, agro-processing, Pulp and paper, leather and textile Buildings and cities Cement, } \\
\text { mining. }\end{array}$ & 3 \\
\hline Energy & Conventional and renewable sources. & 3 \\
\hline Industry & $\begin{array}{c}\text { Chemicals, agro-processing, Pulp and paper, leather and textile Buildings and cities and Cement, } \\
\text { mining. }\end{array}$ & 3 \\
\hline
\end{tabular}

\section{Climate change and food security in Ethiopia}

Ethiopia has emerged as one of the fastest growing economies globally with an average GDP growth of 11 per cent per annum during $2005-06$ to $2009-10$ [28]. Over $41 \%$ of the population is undernourished [29]. In addition, an estimated $11 \%$ of the rural population) are currently considered chronically food insecure, meaning each year they are relying on resource transfers to meet their minimal food requirements. Over the past four 
years between 2.2 and 6.4 million additional people were foodinsecure or not able to meet their food needs in the short term due to transitional factors. They are temporarily dependent on relief food assistance [30]. Drought risk remains one of the key drivers of food insecurity in Ethiopia. Since 1950 As [31] mentions, 'once every three or four years is a drought year' in Ethiopia. Environmental degradation is also a critical factor which exacerbates (soil loss, deforestation, and pest incidence), rapid population growth, poverty, rural-urban migration, and conflict can contribute to food insecurity (Table 3).

Table 3: Chronology of drought-related food security crises since 1950 in Ethiopia [32-34].

\begin{tabular}{|c|c|}
\hline Year & Major Incidences \\
\hline 1953 & Food security crisis in Wollo and Tigray. \\
\hline 1957-58 & $\begin{array}{l}\text { Food security crisis in Tigray, Wollo, and south-central Shewa. About } 1 \text { million farmers in Tigray might have been affected, } \\
\text { with about } 100,000 \text { being displaced. }\end{array}$ \\
\hline $1962-66$ & $\begin{array}{l}\text { Many parts of the northeastern Ethiopia suffered from droughts and Food security crisis. Tigray and Wollo were severely } \\
\text { hit. }\end{array}$ \\
\hline 1973-74 & $\begin{array}{l}\text { This was one of the most significant food security crises which affected parts of eastern Harare, SNNPR and the Bale } \\
\text { lowlands. About } 100,000 \text { to } 200,000 \text { people died as a result of this extensive crisis. }\end{array}$ \\
\hline 1977-78 & $\begin{array}{l}\text { Most parts of the Wollo were severely hit by food security crisis owing to erratic rainfall, pest damage, and frost actions. } \\
\text { About 500,000 farmers were affected }\end{array}$ \\
\hline 1984-85 & $\begin{array}{l}\text { Most parts of Ethiopia including relatively food secure areas like Walaita, Kambata and Hadiya were affected by severe food } \\
\text { insecurity. Drought and crop diseases were the main drivers of the food security crisis in this case. It is estimated that over } \\
\qquad 1,000,000 \text { people died. }\end{array}$ \\
\hline 1987-88 & Tigray, Wollo and Gonder were severely affected due to drought and civil wars. \\
\hline $1990-92$ & Rain failure and regional conflicts resulted in approximately 4,000,000 people being affected. \\
\hline 1993-94 & $\begin{array}{l}\text { Widespread food insecurity, but few deaths or cases of displacement were reported because of early responses by the } \\
\text { government and international aid organizations. }\end{array}$ \\
\hline 2003-04 & Over 13 million people affected, but the response mitigated the worst potential outcomes. \\
\hline 2008-09 & Almost 3 million people were affected \\
\hline 2011 & Severe food security crisis occurred in the southeastern lowlands. This was linked to unprecedented drought. \\
\hline
\end{tabular}

\section{Climate Change and Crop Production}

Cereal production in Ethiopia (teff, wheat, barley, and maize) has almost quadrupled between 1961 and 2010. Overall in this period, cereal production has increased steadily with some declines between 1973 and 1975, and again in 1984/1985this trend is linked to the impact of major droughts in Ethiopia during these years. Yields have also increased steadily in this period with a relatively stable yield between 1975 and 1993, followed by a rapid increase thereafter (Figure 6).

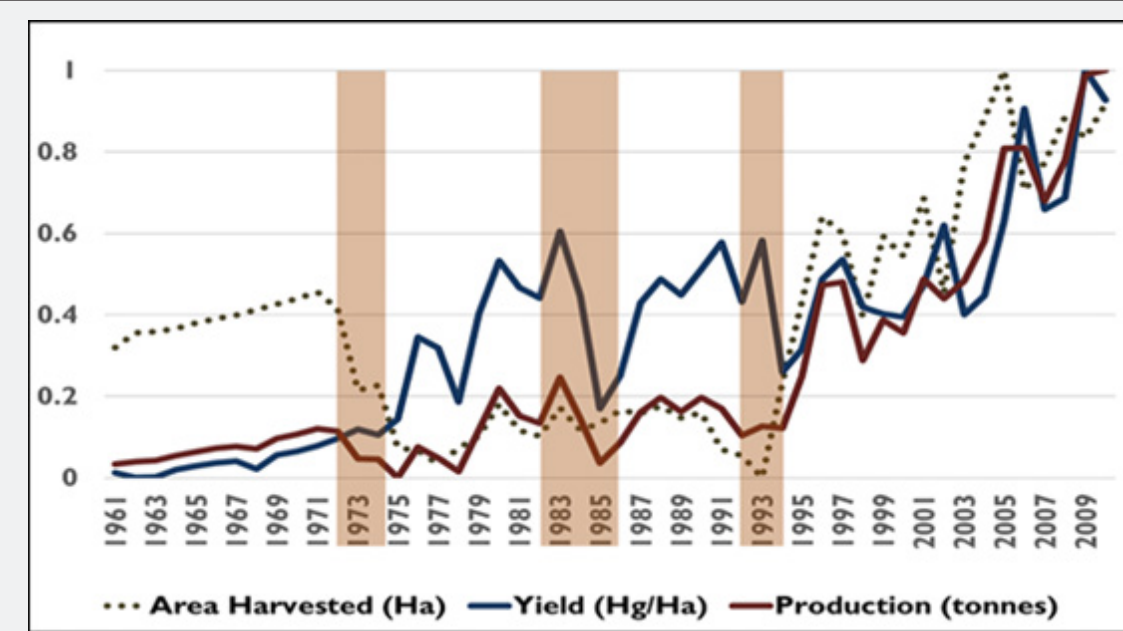

Figure 6: Cereal crop production trends and key drought events, 1961-2010 [35].

A Lower rainfall (both belg and kiremt) is linked to reduced planting opportunities. For instance, lower rainfall in 2000-
2002, 2008, 2009, and 2011 were associated with less land being cultivated (higher missed planting opportunities) (Figure 7). 


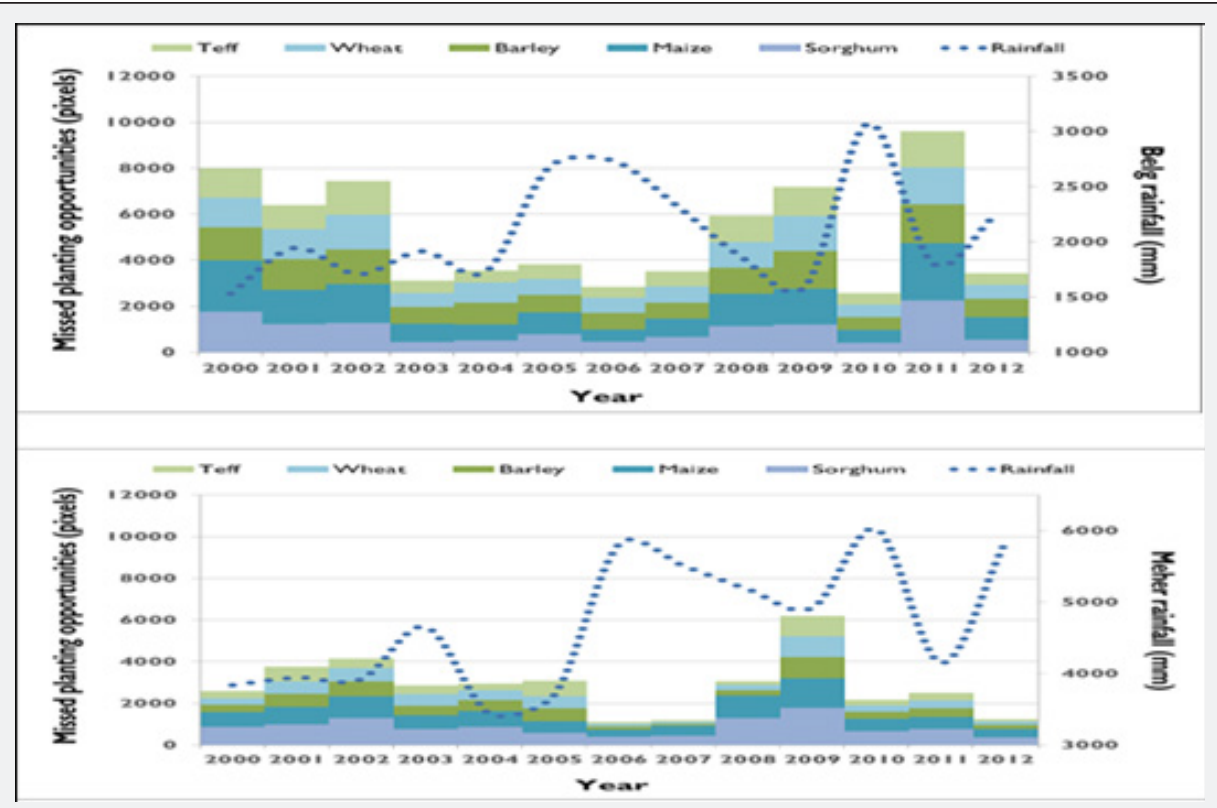

Figure 7: Missed planting opportunities for teff, wheat, barley, maize, and sorghum, and rainfall trends during the belg (left) and kiremt (right) seasons. Missed planting is measured in terms of the number of pixels (area) that could be cultivated with a specific crop but were not planted in a particular season or year7 [36,37].

According to a study in the Abay and Baro-Akobo River Basins of Ethiopia, farmers perceived recent climate change as a decrease in rainfall [38]. In terms of impacts, about $77 \%$ respondents reported a reduction in crop production while $60 \%$ reported a reduction in length of crop growing period, linked to a failure of belg rains. The study found out that local people associated the following events with climatic variability: increased incidence of insects (79\%), increased plant diseases (62\%), increased weeds (44\%), and shifts of suitable areas for major crops (59\%). This highlights that climate variability can have different impacts on crops (Figure 8).

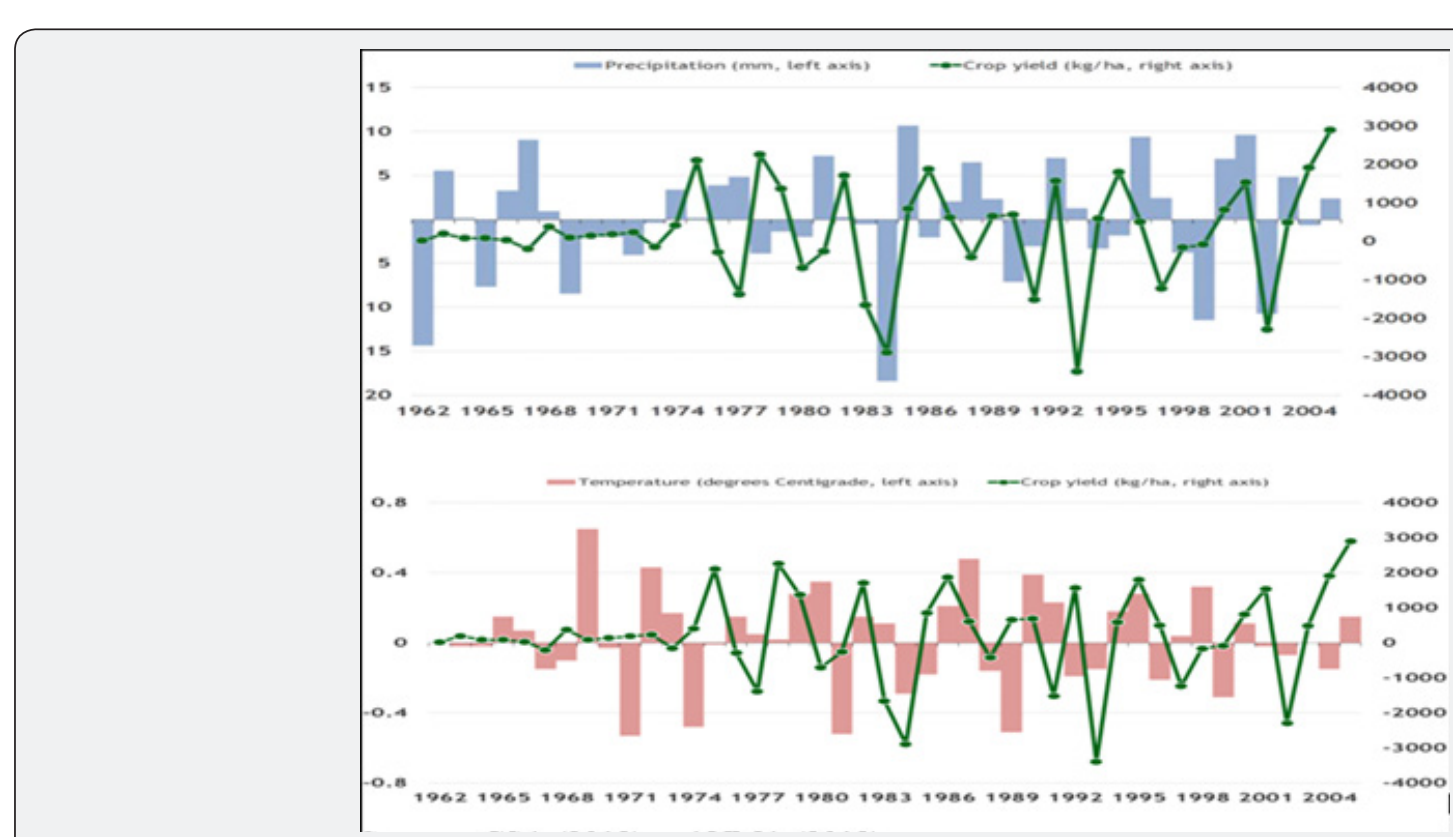

Figure 8: Relationship between precipitation (top) and temperature (bottom) with crop yield first differences (Sources: CSA, 2012) [37].

\section{Climate change and agroforestry}

Agroforestry is well-known buffering and resilience effects (Climate variability is well buffered by agroforestry because of permanent tree cover and varied ecological niches and resilience or recovering after a disturbance (e.g. extreme weather events or market failure) is well performed by agroforestry because of diversified temporal and spatial management options $[18,39$ 41]. 
Examples of criteria for the sustainability attributes of agroforestry (Permanent tree cover protects and improves the soil, while increasing soil carbon stocks, Diversification of commodities allows for adjustment to market needs, Management flexibility is compatible with shifts in labor supply, and Non-harvested components play an important protective role.

Today's climate change context confirms the potential of agroforestry ( Climate-smart agriculture gives trees a large importance, Conservation agriculture (no-till + cover crops) mimics the protective cover of trees (see next photo), Sustainability attributes of agroforestry are strong assets for climate change adaptation, And Carbon sequestration by trees contributes to climate change mitigation).

The double potential of agroforestry to address climate change issues (Greenhouse gas-mitigation strategy through carbon sequestration because of greater efficiency of integrated systems in resource (nutrients, light, and water) capture and utilization than single-species systems [42], and Sustainable adjustment to changing conditions because agroforestry systems can be called perennial farming systems. They maintain and develop their root and woody biomass throughout seasons while providing food, fiber, energy and vegetative cover for soils.

Agroforestry can boost synergy between adaptation to and mitigation of climate change (High biodiversity and resulting ecosystem services in agroforestry also contribute to synergy between adaptation and mitigation and Agroforestry improved fallows provide an example of such synergy).

A new paradigm is required for designing climate-smart agroforestry associations (So far, agroforestry has mainly been a crop system and a tree system side by side, a new agroforestry paradigm is required where trees and crops are selected and managed together, and such innovative associations will be able to address food security and climate change issues in simultaneity) (Figure 9) [43,44].

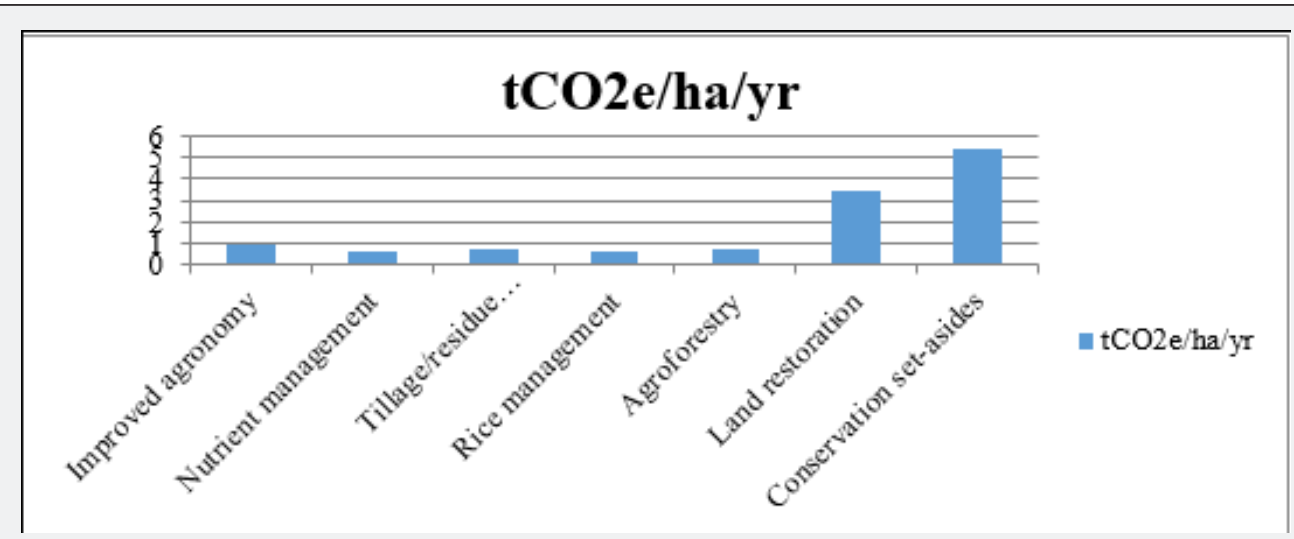

Figure 9: Carbon potential of conservation agriculture Practices (Source: P. Smith et al. 2007).

Agroforestry in context of climate change adaptation and mitigation

Agroforestry has huge potential to adapt and mitigate climate change. Many of the time we talk about adaptation and mitigation strategies of agroforestry in context with global warming, but we need to explain these key words. Agroforestry provides a unique opportunity to reconcile the objectives of mitigation and adaptation to climate change (Table 4).

Table 4: Measures of climate change adaptation and mitigation through agroforestry [45].

\begin{tabular}{|c|c|c|}
\hline $\begin{array}{l}\text { Climate Change } \\
\text { Activity }\end{array}$ & Major CC Functions & Agroforestry Role \\
\hline \multirow{5}{*}{$\begin{array}{l}\text { Mitigation Activities } \\
\text { that reduces GHGs in the } \\
\text { atmosphere or enhance } \\
\text { the storage of GHGs } \\
\text { stored in ecosystems }\end{array}$} & Sequester carbon & Accumulate $\mathrm{C}$ in woody biomass and in soil \\
\hline & Reduce GHG emission & $\begin{array}{l}\text { Reduce fossil fuel consumption (reduce equipment runs in areas with trees and } \\
\text { Reduce farmstead heating and cooling), }\end{array}$ \\
\hline & & Reduce $\mathrm{CO}_{2}$ emission by $\mathrm{C}$ sink \\
\hline & & $\begin{array}{l}\text { Reduce N20 emissions (By greater nutrient uptake through tress and by reducing } \\
\text { N fertilizer consumption in tree systems) and }\end{array}$ \\
\hline & & Enhance forage quality, thereby reducing $\mathrm{CH}_{4}$. \\
\hline $\begin{array}{l}\text { Adaptation Action to } \\
\text { reduce or eliminate the } \\
\text { negative effects of CC or } \\
\text { take advantage of the } \\
\text { positive effects }\end{array}$ & $\begin{array}{l}\text { Allow species to mitigate to } \\
\text { more favorablea conditions }\end{array}$ & Provide habitat corridors for species migration. \\
\hline
\end{tabular}




\begin{tabular}{|l|c|c|}
\hline & $\begin{array}{c}\text { Reduce threats and enhance } \\
\text { resilience }\end{array}$ & $\begin{array}{c}\text { Amelioration of microclimate to reduce impact of extreme weather events on crop } \\
\text { production, to maintain quality \& quantity of forage, to reduce livestock stress, } \\
\text { Provide greater habitat diversity to support organisms (e.g. native pollinators \& } \\
\text { useful insects), Provide greater structural and functional diversity, to maintain } \\
\text { and protect natural resources and Create diversified production opportunities to } \\
\text { reduce risk under fluctuating climate. }\end{array}$ \\
\hline
\end{tabular}

\section{Conclusion}

Carbon sequestration potential of agroforestry is greater than other land use system because due to presence of perennial tree in the component. In addition, agroforestry showed a great potential in sequester carbon and contribute to mitigating $\mathrm{CO}_{2}$ than treeless systems. Agroforestry systems can be advantageous over conventional agricultural system, and forest production methods. They can offer increased productivity, food security, economic benefits, and more diversity in the ecological goods and services provided. In sector wise basis, agriculture contributes $80 \%$ of GHG emission because due to dominant position of livestock farming (methane emissions) in Ethiopia's economy also influences the relative contribution of GHG to the total emissions. Agroforestry provides assets and income from carbon, wood energy, improved soil fertility and enhancement of local climate conditions; it provides ecosystem services and reduces human impacts on natural forests. Most of these benefits have direct benefits for local adaptation while contributing to global efforts to control atmospheric greenhouse gas concentrations. There is need to build a bridge between adaptation and mitigation measures for creating environmental secure options of carbon sequestration with multifunctional benefits from agroforestry.

\section{Recommendation}

Based on the results of this review, the following recommendations are suggested to be considered in the future intervention strategies;

a) Agroforestry have a pronounced assistance for sinking carbon concentrated in the atmosphere. Therefore, decision makers should have to be encouraging climate smart agroforestry practices to mitigate the globally facing climate change challenges that affect the amount and quality of living thing.

b) This seminar paper suggested that encouraging farmers, Governments, different organization and others to practices agroforestry system for ensuring food security and reducing climate change impact.

c) Introduction of new agroforestry technologies that goes in line with the changing climate patterns should be the prior agenda for researcher and development planners in order to improve food security.

d) Promoting mixed agriculture/agroforestry through improved crop, tree and livestock to diversify livelihood of the farmers in order to resist climate change risk. e) Facilitate research and extension services to provide adequate information services to the farmers to implementing agroforestry system rather than monocropping.

f) Every countries, Governments, NGOs, Rancher, and pastoralists should have provided highly concentrated feed to reduce methane emission from livestock's due to enzyme that promote methane in the animal digestion organ.

\section{References}

1. Kumar BM, Nair PKR (2011) Carbon Sequestration Potential of Agroforestry Systems: Opportunities and Challenges. In: Kumar BM, Nair PKR (Eds.), Advances in Agroforestry.

2. Clark H, de Klein C, Newton P (2001) Potential management practices and technologies to reduce nitrous oxide, methane and carbon dioxide emission from New Zealand agriculture. Ministry of Agriculture and Forestry, New Zealand, p. 85.

3. Charles RL, Emmanuel F Nzunda, Munishi PKT (2014) Agroforestry as a resilient strategy in mitigating climate change in mwanga district, kilimanjaro, Tanzania. Global Journal of Biology, Agriculture and Health science 3(2): 11-17.

4. Nair PKR (2011) Carbon sequestration studies in agroforestry systems: a reality-check. Agroforestry systems 86(2): 243-253.

5. King KFS (1987) The history of agroforestry. In: Steppler HA, Nair PKR (Eds.), Agroforestry: A Decade of Development, ICRAF, Nairobi, Kenya, pp. 1-11.

6. Conklin HC (1957) Hanundo Agriculture.

7. Ojo GJA (1966) Yoruba Culture. University of Ife and London Press, London, UK.

8. Nair PKR (1985a) Classification of agroforestry systems. Agroforestry Systems 3(2): 97-128.

9. Felker P (1978) State-of-the-art: Acacia albida as a Complementary Intercrop with Annual Crops. Report to USAID. University of California, Riverside, CA, USA

10. Miehe S (1986) Acacia albida and other multipurpose trees on the Fur farmlands in the Jebel Marra highlands, Western Dafur, Sudan. Agroforestry Systems 4(2): 89-119

11. Vandenbeldt RJ (1992) Faidherbiaalbida in the West African Semi-Arid Tropics. ICRISAT, Hyderabad, India and ICRAF, Nairobi, Kenya.

12. Mann HS, Saxena SK (1980) "Kherji” (Prosopis cineraria) in the Indian Desert: It's Role in Agroforestry. In: Mann HS, Saxena SK (Eds.), CAZRI Monograph 11. Central Arid Zone Research Institute, Jodhpur, India.

13. Shankarnarayan KA, Harsh LN, Kathju S (1987) Agroforestry systems in the arid zones of India. Agroforestry Systems 5(1): 69-88.

14. Nair PKR (1987) Agroforestry and firewood production. In: Hall DO, Overend RP (Eds.), Biomass, John Wiley, Chichester, UK, pp. 367-386.

15. Fernandez ECM, Nair PKR (1986) An evaluation of the structure and function of tropical home gardens. Agricultural Systems 21(4): 279310 . 
16. de la Peña R, Hughes J (2007) Improving Vegetable Productivity in a Variable and Changing Climate. ICRISA An Open Access Journal 4(1): $1-22$.

17. IPCC (2000) Land use, Land-use Change, and Forestry. A Special Report of the IPCC. Cambridge University Press Cambridge, UK.

18. Torquebiau E (1992) Are tropical agroforestry homegardens sustainable. Agriculture, Ecosystems and Environment 41(2): 189207.

19. Climate Change National Adaptation Plan of Action of Ethiopia, 2007.

20. NMA (National Meteorological Agency) (2007) National Meteorology Agency: Final Report on Evaluation Criteria for Identifying High Priority Adaptation Activities prepared by B and M Development Consultants for NMA. Addis Ababa, Ethiopia.

21. Oxfam (2010) Poverty, Vulnerability and Climate Variability in Ethiopia. International Research report. Addis Ababa, Ethiopia.

22. Korecha D, Barnston AG (2007) Predictability of June-September Rainfall in Ethiopia. Monthly Weather Review 135(2): 628-650.

23. Seleshi Y, Zanke U (2004) Recent changes in rainfall and rainy days in Ethiopia. International journal of climatology 24(8): 973-983.

24. First (2001) Initial National Communication of Ethiopia to the United Nations Framework Convention on Climate Change (UNFCCC). Report of the Federal Democratic Republic of Ethiopia, Ministry of Water Resources, National Meteorological Services Agency.

25. EPA (2012) National Report of Ethiopia, the United Nations Conference on Sustainable Development (Rio+20). Addis Ababa: Federal Democratic Republic of Ethiopia.

26. UNDP Ethiopia (2011) Framework for UNDP Ethiopia's Climate Change, Environment, and Disaster Risk Management Portfolio.

27. Wondwossen Sintayehu (2013) National Greenhouse Gas Emissions Baseline Scenarios Learning from Experiences in Developing Countries. The Danish Energy Agency (DEA), the Organization for Economic Cooperation and Development (OECD) and the UNEP Risø Centre (URC).

28. MoFED (2010) the Federal Democratic Republic of Ethiopia: Growth and Transformation Plan (2010-2014/15), Draft Document: Addis Ababa.

29. FAO/WFP [Food and Agriculture Organisation and World Food Programme] (2010) State of Food Insecurity in the World. Rome: FAO/ WFP.
30. FAO/ WFP (2012) Crop and Food Security Assessment Mission to Ethiopia. Rome/Addis Ababa: FAO/WFP. April 2012.

31. Woldeamlak B (2009) Rainwater Harvesting as a Livelihood Strategy in the Drought-Prone Areas of the Amhara Regions of Ethiopia. Addis Ababa: Organization for Social Science Research in Southern and Eastern and Southern Africa.

32. Markos E (1997) Demographic Response to Ecological Degradation and Food Insecurity in Drought Prone Areas in Northern Ethiopia. Ph.D. Thesis, The University of Groningen.

33. Webb P, von Braun J, Yohannes Y (1992) Famine in Ethiopia: Policy Implications of Coping Failure at National and Household Levels. International Food Policy Research Institute. Research Report No. 92. Washington, D.C.: IFPRI.

34. Cochrane L (2011) Food Security or Food Sovereignty: The Case of Land Grabs.

35. Fao/Stat (2012) Crop production statistics

36. LEAP (2013) Information provided by Dr. Muktar Reshid.

37. NMA (2012) Weather station data. Obtained by request.

38. Bewket W, Alemu D (2011) Farmers' perceptions of climate change and its agricultural impacts in the Abay and Baro-Akobo River Basins, Ethiopia. Ethiopian Journal of Development Research 32(2).

39. Sanchez PA (1995) Science in agroforestry. Agroforestry Systems 30(12): 5-55.

40. Huxley P (1996) Tropical agroforestry. Blackwell Science, pp.371.

41. Garrity D, Akinnifesi FK, Ajayi OC, Weldesemayat SG, Mowo JW, et al. (2010) Evergreen agriculture: a robust approach to sustainable food security in Africa. Food Sec 2(3): 197-214.

42. Nair PKR, Kumar BM, Nair VD (2009) Agroforestry as a strategy for carbon sequestration. J Plant Nutr Soil Science 172(1): 10-23.

43. Nair PKR (1985b) Agroforestry in the context of land clearing and development in the tropics.

44. NMA-NAPA (2007) Climate change National Adaptation Program of Action (NAPA) of Ethiopia. Ministry of Water Resources, Addis Ababa.

45. Schoeneberger M, Bendrub G, Gooijer H, Soolanayakanahal R, Tom Sauer, et al. (2012) Branching out: agroforestry as a climate change mitigation and adaptation for agriculture. Journal of Soil and Water Conservation 67(5): 128-136.

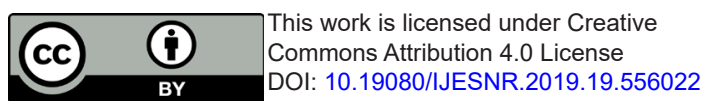

Your next submission with Juniper Publishers
will reach you the below assets
- Quality Editorial service
- Swift Peer Review
- Reprints availability
- E-prints Service
- Manuscript Podcast for convenient understanding
- Global attainment for your research
- Manuscript accessibility in different formats
( Pdf, E-pub, Full Text, Audio)
- Unceasing customer service
Track the below URL for one-step submission
https://juniperpublishers.com/online-submission.php

